\title{
An Ancestral Caddo Ceramic Vessel from the Mack Spence Site (41CS6) in the Sulphur River Basin in East Texas
}

Timothy K. Perttula

Follow this and additional works at: https://scholarworks.sfasu.edu/ita

Part of the American Material Culture Commons, Archaeological Anthropology Commons, Environmental Studies Commons, Other American Studies Commons, Other Arts and Humanities Commons, Other History of Art, Architecture, and Archaeology Commons, and the United States History Commons

Tell us how this article helped you.

This Article is brought to you for free and open access by the Center for Regional Heritage Research at SFA ScholarWorks. It has been accepted for inclusion in Index of Texas Archaeology: Open Access Gray Literature from the Lone Star State by an authorized editor of SFA ScholarWorks. For more information, please contact cdsscholarworks@sfasu.edu. 
An Ancestral Caddo Ceramic Vessel from the Mack Spence Site (41CS6) in the Sulphur River Basin in East Texas

\section{Creative Commons License}

\section{(c) (1) \&}

This work is licensed under a Creative Commons Attribution-NonCommercial 4.0 International License 


\title{
An Ancestral Caddo Ceramic Vessel from the Mack Spence Site (41CS6) in the Sulphur River Basin in East Texas
}

\author{
Timothy K. Perttula
}

There is a single ancestral Caddo ceramic vessel in the vessel collections at the Texas Archeological Research Laboratory at The University of Texas at Austin from the Mack Spencer site (41CS6) near the Sulphur River in Cass County, in East Texas (Figure 1). The 2D documentation of the vessel is put on record in this article.

Natural Regions of Texas

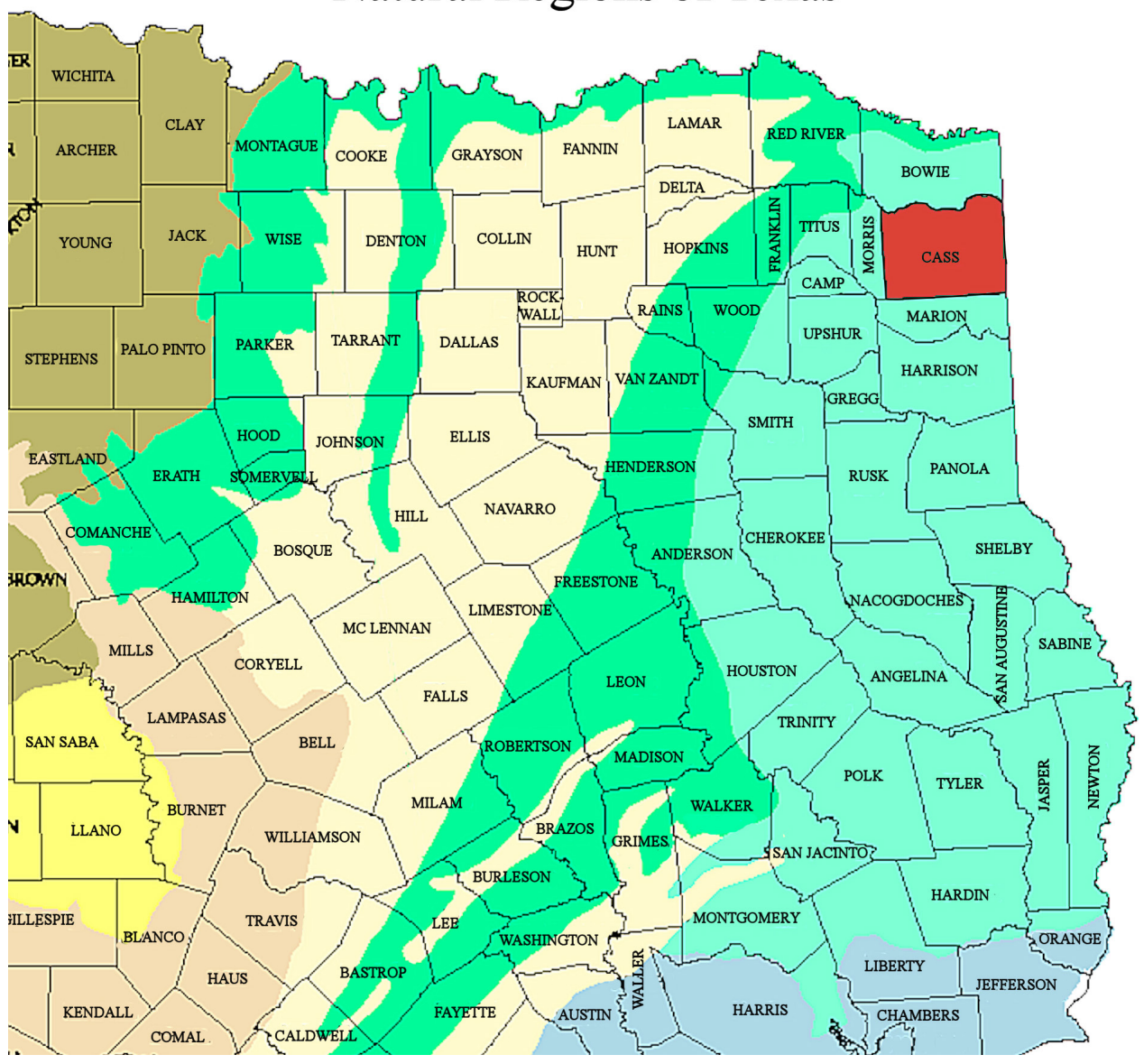

Figure 1. The general location of Cass County, Texas, and the Mack Spence site in East Texas.

The vessel from the Mack Spence Farm, 3.5 miles east of Naples, was found several years before 1930. There were ceramic vessel sherds on the surface of the site at that time.

SITE NAME OR SITE NUMBER: Mack Spence

VESSEL NO.: 1

VESSEL FORM: Jar with a tall rim 
NON-PLASTICS AND PASTE: grog and hematite

RIM AND LIP FORM: Direct rim and rounded lip

CORE COLOR: $\mathrm{G}$ (fired in a reducing environment and cooled in the open air)

INTERIOR SURFACE COLOR: dark gray; fire clouds on the rim

EXTERIOR SURFACE COLOR: yellowish-brown; fire clouds on the rim and body

WALL THICKNESS (IN MM): rim, $4.8 \mathrm{~mm}$

INTERIOR SURFACE TREATMENT: smoothed

EXTERIOR SURFACE TREATMENT: smoothed

HEIGHT (IN CM): 11.0

ORIFICE DIAMETER (IN CM): 9.2

DIAMETER AT BOTTOM OF RIM OR NECK (IN CM): 9.0

BASE DIAMETER (IN CM) AND SHAPE OF BASE: $5.7 \mathrm{~cm}$, circular and flat

ESTIMATED VOLUME (IN LITERS): 0.6

DECORATION (INCLUDING MOTIF AND ELEMENTS WHEN APPARENT): The eroded rim has at least six horizontal engraved lines, and the vessel body is plain.

PIGMENT USE AND LOCATION ON VESSEL: none

TYPE AND VARIETY (IF KNOWN): Unidentified fine ware, but possibly Hickory Engraved (see Suhm and Jelks 1962:71 and Plate 36j)

The possible Hickory Engraved vessel from the Mack Spence site suggests that the site may have been occupied during the Early Caddo period, from ca. A.D. 900-1200. It is likely that the site was used by ancestral Caddo peoples for both domestic and mortuary functions.

\section{Acknowledgments}

Thanks to the staff at the Texas Archeological Research Laboratory for access to their vessel collections. Lance Trask prepared Figure 1 for the article.

\section{References Cited}

Suhm, D. A. and E. B. Jelks (editors)

1962 Handbook of Texas Archeology: Type Descriptions. Special Publication No. 1, Texas Archeological Society, and Bulletin No. 4, Texas Memorial Museum, Austin. 